\title{
Assessment of long-term changes in the surface air temperature from the High Arctic archipelago Franz Joseph Land from 1929 to the present (2017)
}

\author{
Boris Ivanov ${ }^{1,2^{*}}$, Tatiana Karandasheva ${ }^{1}$, Valery Demin $^{3}$, Anastasiia \\ Revina ${ }^{1}$, Pavel Sviashchennikov ${ }^{2,}{ }^{1}$, Ketil Isaksen ${ }^{4}$, Eirik J. Førland ${ }^{4}$, \\ Øyvind Nordli ${ }^{4}$, Herdis Motrøen Gjelten ${ }^{4}$ \\ ${ }^{1}$ Arctic and Antarctic Research Institute, Bering str. 38, Saint-Petersburg, 199397 Russia \\ ${ }^{2}$ Saint-Petersburg State University, Universitetskaya Emb. 7/9, St. Petersburg 199034, \\ Russia \\ ${ }^{3}$ Polar Geophysical Institute, Academgorodok St. 26a, Apatity, 184209, Russia \\ ${ }^{4}$ Norwegian Meteorological Institute, Henrik Mohns plass 1, Oslo, Norway
}

\begin{abstract}
Electronic archives of data from standard meteorological observations (mean daily/monthly surface air temperatures - SAT) at the meteorological stations at Bukhta Tikhaya (Hooker Island, 1929-1960) and Krenkel Observatory (Hayes Island, 1957-2017) on Franz Josef Land (FJL) are presented. Parallel data series of SAT made in 1958 and 1959 on both meteorological stations were analyzed. Linear regression equations used for extrapolation of observational data representative for Krenkel Observatory for the period 1929-1957 are also presented. The assessment of long-term changes in SAT on FJL was carried out based on the analysis of the obtained series (1929-2017). The main conclusions that follow from our study are: (1) The total warming in the FJL archipelago was $1.6-1.8^{\circ} \mathrm{C}\left(0.2^{\circ} \mathrm{C} /\right.$ decade $)$ for the entire available period of instrumental observations (1929-2017); (2) The highest rates of warming were recorded in March-April and amounted to $0.6^{\circ} \mathrm{C} /$ decade; (3) A particular strong warming has been observed since the $1990 \mathrm{~s}$. The annual temperature increased by $6.3^{\circ} \mathrm{C}\left(2.2^{\circ} \mathrm{C} /\right.$ decade $)$ for the period 1990 2017 and $5.2^{\circ} \mathrm{C}\left(2.9^{\circ} \mathrm{C} /\right.$ decade $)$ for the period $2000-2017$; (4) For the period 1990-2017 the maximum rate of warming occurred between October to February with $4.4^{\circ} \mathrm{C} / \mathrm{dec}-$ ade; (5) For the period 2000-2017 the maximum rate of warming occurred between January to April and from November to December with $5.6^{\circ} \mathrm{C} /$ decade; (6) The dominant seasons of the year are winter (November-April), spring (May), summer (June-September) and autumn (October); (7) Over the entire observation period the largest temperature increase was observed in the winter season. During the period of modern warming (1990-2017), the largest temperature increase was observed in winter and autumn.
\end{abstract}

DOI: $10.5817 / C P R 2021-1-9$

Received October 10, 2020, accepted June 20, 2021.

${ }^{*}$ Corresponding author: B. Ivanov $<$ b_ivanov@aari.ru $>$

Acknowledgements: This work was carried out in accordance with the Roshydromet project "Monitoring of the state and pollution of the environment, including the cryosphere, in the Arctic basin and in the areas of the research base "Ice Base Cape Baranova", Tiksi Hydrometeorological Observatory and the Russian Science Center at Svalbard Archipelago" and the Polar Geophysical Institute (Apatity) project "Carrying out stationary observations of magnetic and optical phenomena on the Spitsbergen archipelago, study of geophysical processes in the high-latitude atmosphere of the Earth" . We are extremely grateful to the Norwegian Meteorological Institute because these studies were supported by Russian-Norwegian "Agreement in area of analysis of climate and sea ice data in the North part of Barents Sea" (2019-2020), financed by the Ministry of Climate and Environment in Norway (RUS-19/0001). 
Key words: High Arctic, climate series, climate changes

List of abbreviations: AARI - Arctic and Antarctic Research Institute, FJL - Franz Josef Land, MGO - Main Geophysical Observatory, RRHMI-WDC - Russian Research Hydro-Meteorological Institute-World Data Center, SAT - surface air temperature, $\mathrm{SD}$ - standard deviation

\section{Introduction}

There are relatively few studies of longterm climate changes and their processes available for the region of the Franz Joseph Land (FJL) archipelago in comparison with Svalbard. This is due to the inaccessibility of the archipelago and relatively short homogeneous climatic series of instrumental observations. The earliest instrumental observations revealed a significant difference in the change in the annual course of surface air temperature and atmospheric pressure between the periods 1872-1905 and 1961-1990 (Przybylak et al. 2010, 2012; Przybylak 2000). Historical irregular observations, and especially observations under the program of the First International Polar Year (1882$1883)$, recorded colder winters in the period 1872-1905 compared with the period 1961-1990 (the previous WMO standard reference period for long-term climate change assessments) and almost no differences in the summer months (Przybylak et al. 2012). Analysis of temperature data from expeditionary research (1899-1914) showed that the meteorological conditions in this period were considerably colder than in the modern period (1981-2010). Observations made in 1930-1931, which can be attributed to the period of the "early" warming of the twentieth century, showed that this was a relatively warm period (Arazny et al. 2019). Several papers have been devoted to the analysis of changes in precipitation and snow depth observed at meteorological stations in the archipelago, e.g. Aleksandrov et al. (2005), Bryzgin and Voskresenskiy (2000), and Aleksandrov et al. (2003). The moisture content of the atmosphere plays an important role in the Arctic climate in FJL. The integral moisture content of the atmosphere recorded at Krenkel weather station in Hayes Island showed a slight increase in the period 1961-1980 (Burova 1988, 2000). The first regular radiation observations at Bukhta Tikhaya (Hooker Island) that begun in 1932 made it possible for the first time to estimate the characteristic values of the short-wave and longwave radiation fluxes, as well as their seasonal variability (Gavrilova 1963). Radiation observations have taken place at the Krenkel meteorological station since 1957. These observations were summarized in a special archive (Radionov 1997) in the form of average monthly components of the radiation balance of the underlying surface for the period 1958-1992. Obtained values of incoming, reflected, diffuse radiation and net radiation balance in this archive make it possible to estimate the spatial variability of radiation fluxes in the Russian Arctic. Cloudiness is a significant factor affecting radiation fluxes. In the Arctic, it has the specific property of greatest transparency compared to other regions of the Earth. Long-term radiation observations conducted at the Krenkel meteorological station showed no significant trends in the values of total radiation and lower cloud cover for the period 19581992. At the same time, a significant decrease in direct solar radiation was recorded, which is associated with an increase in the optical thickness of the atmosphere due to an increase in the number of aerosols (Marshunova et al. 2000). 
Most of the published scientific results cover the period of 1958-1995. Observations before and after this period were irregular. In this respect, scientific research aimed at creating long homogeneous time series is of particular importance. This is essential for the evaluation and analysis of long-term trends in climate change in the archipelago and comparison with adjacent areas in the West Arctic. The most detailed analysis of the climate of the archipelago was carried out by Vize (1930), Krenke (1996) and Dzhenyuk (2014).

Climate changes observed during the past 30 years are especially pronounced in the Arctic region, where positive anomalies of average annual air temperature in some places reach $3-4^{\circ} \mathrm{C}$ in respect to

\section{Material and Methods}

To study climate change at the FJL, two meteorological stations were selected (Bukhta Tikhaya and Krenkel Observatory). Russian regular instrumental meteorological observations at the FJL cover the period from 1929 to the present. The location of the studied stations in the northern part of the Barents Sea (there are no other stations in this region) and the early start of observations in this region are extremely important for the study of changes and variability of the Arctic cli-
1961-1990 (Bekryaev et al. 2010, Gjelten et al. 2016, Ivanov 2019, Nordli et al 2014). The Arctic region is the most sensitive to recent changes in the global climate. Conducting long-term research of climate in the Polar Regions allows to estimate the spatial and temporal scales of these changes. Important data in such studies are obtained from instrumental meteorological observations made at a network of Norwegian, Russian and Polish Arctic stations.

The purpose of this study is to create a homogeneous series of monthly average SAT values for the entire available period of Russian regular instrumental observations and to assess long-term climate changes.

mate in this region. At present, only one meteorological station (Krenkel Observatory), located on the Hayes Island, operates on the FJL. At the same time, according to studies performed at the AARI (Moskal 1972), it is believed that the observations made at the Bukhta Tikhaya station are the most representative for the northern and northeastern parts of the Barents Sea for weather forecasting. The location of meteorological stations in the area is presented in Fig. 1.

\section{The history of the meteorological observations at the stations Bukhta Tikhaya and Krenkel Observatory}

Regular instrumental meteorological observations at the Bukhta Tikhaya station began on September $1^{\text {st }}, 1929$ and ended on February $29^{\text {th }}$, 1960. The station was located on Hooker Island in the southwestern part of the archipelago $\left(80^{\circ} 20^{\prime} \mathrm{N}\right.$, $\left.52^{\circ} 46^{\prime} \mathrm{E}\right)$. The elevation of the observation site was $5.9 \mathrm{~m}$ above sea level (a.s.l.). In September 1932, the site was moved to the North and North-East. The new elevation of the station was $8.4 \mathrm{~m}$ a.s.l. In July 1959 , the meteorological site was again relocated and its new elevation was $16.2 \mathrm{~m}$ a.s.l. These shifts were several meters in both cases, which did not affect the coordinates, taking into account the accuracy of their determination at that period. 


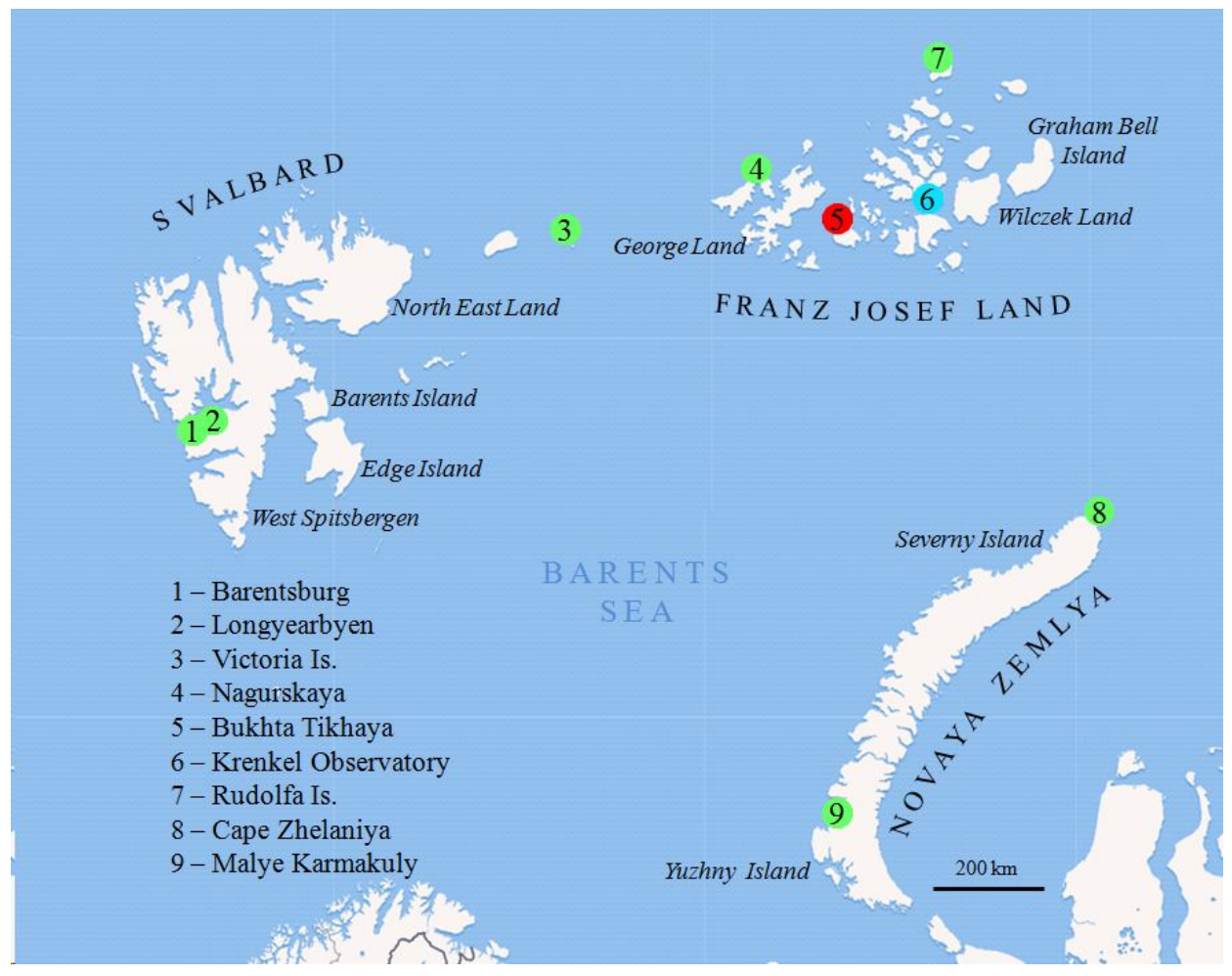

Fig. 1. Location of meteorological stations.

Regular instrumental meteorological observations at the station Krenkel Observatory began on November $1^{\text {st }}, 1957$ and, with only a short break (2001-2004) because of a fire, continue to this day. The station is located on Hayes Island in the central part of the archipelago $\left(80^{\circ} 37 \mathrm{~N}\right.$ and $\left.58^{\circ} 03^{\prime} \mathrm{E}\right)$. The meteorological site is located at an elevation of $21 \mathrm{~m}$ a.s.l. There have been no relocations or instrumental changes at Krenkel Observatory. The distance between the two stations is about $100 \mathrm{~km}$. The location of the stations is shown in Fig. 2.

In winter, a stable land-fast ice, as a rule, is observed in the region around Hayes Island, and stationary polynya is often formed south of Hooker Island (the adjacent Barents Sea) (Shapkin et al. 2021). In summer, the southern areas of the archipelago are significantly affected by the adjacent waters of the northern part of the Barents Sea, and drifting ice can be observed in the central part of the archipelago. These circumstances, other conditions being equal (e.g. atmospheric circulation) define the major differences in the temperature regime of SAT in the both areas (Moskal 1972). Until 1936, observations at meteorological stations were carried out three times a day at 07, 13, 19 (local solar time). From 1936 to 1966, observations were carried out four times a day at 01, 07, 13, 21 (local solar time). Finally, from 1966 to the present - 8 times a day (the main synoptic dates) at 00,03 , 06, 09, 12, 15, 18, 21 (Moscow (winter) standard time). Since January $1^{\text {st }}, 1993$, all observations have been made in UTC. The changes in the timing and number of observations can cause systematic discrepancies in the estimates of the mean daily and 
monthly SAT values. Usually, 3 - and 4 - daily observations lead to an underestimation of the true values of the mean daily SAT due to the neglect of low night temperatures at high and moderate latitudes (Alisov et al. 1952, Drozdov at al. 1989). Moreover, these differences depend on the season of the year, geographical latitude and a number of other factors (topography, etc.). In such cases, special corrections are used to the average values obtained from 3 or 4 daily observations in order to as closely as possible represent the true mean value. These corrections are calculated as the difference between the true average and the average calculated from 3 or 4 daily observations. The true average SAT value is calculated from hourly observations by station thermograph. At the stations where there is no thermograph, the corrections are calculated using data from nearby stations with a similar landscape (f.e. Malie Karmakuly, Novaya Zemlya, $\left.72^{\circ} 22^{\prime} 24^{\prime \prime} \mathrm{N}, 52^{\circ} 43^{\prime} 0^{\prime \prime} \mathrm{E}\right)$.

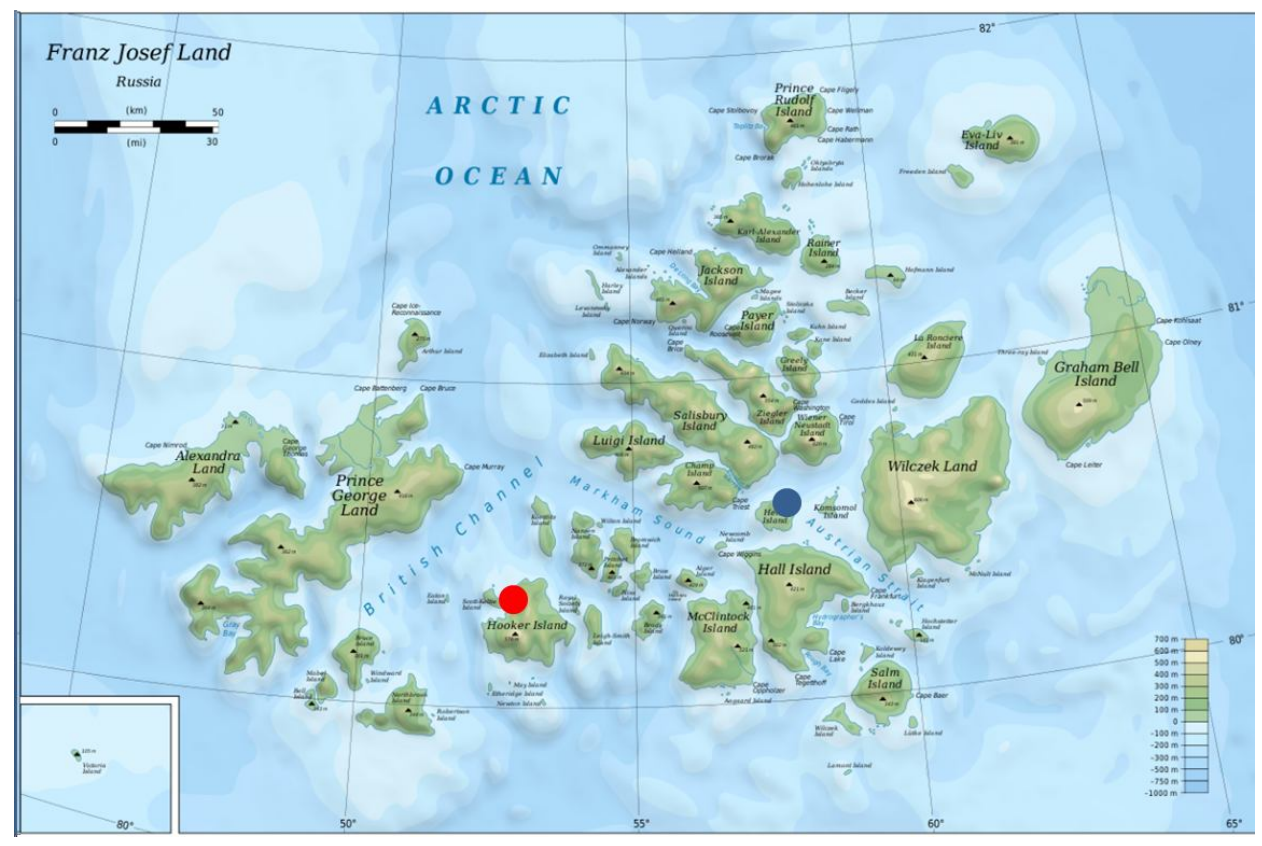

Fig. 2. Frantz Josef Land Archipelago ${ }^{[1]}$, Bukhta Tikhaya station (red outline), Krenkel Observatory (blue).

\section{Data sets}

To create a composite (combined) series of mean monthly SAT values, we used the existing electronic archives of meteorological observation data at the Bukhta Tikhaya station (1929-1960) and Krenkel Observatory (1957-2017), including special archives of mean monthly SAT values, as well as archives containing infor- mation on daily average SAT, maximum and minimum. Information on mean monthly SAT values for the Bukhta Tikhaya station (until 1956) was obtained from the climate reference (USSR climate reference, 1956). Mean monthly SAT values for 1957-1960 were obtained by averaging mean daily SAT values. An electronic ar- 
chive with mean daily values was obtained by digitizing handwritten books of meteorological observations (TM-1) stored in the AARI funds.

Information on meteorological observations at the Krenkel Observatory station (mean monthly and daily SAT values) were collected from various sources. One of the main sources: RRHMI-WDC website (Obninsk, Russian Federation, [2]). The missing information were obtained from TM-1 (AARI funds, [3]), as well as from the website of National Centers for Environmental Information (Asheville, USA, [4]).

The observations included in the electronic archive of mean monthly data for the Krenkel Observatory station cover the period from 1957 to 2017 and include the same set of values as the archive for the
Bukta Tikhaya station. Thus, using various available sources of information, the most complete electronic archives of mean monthly SAT values for the entire period of instrumental observations for the stations under consideration were formed. All meteorological observations presented in the archives underwent preliminary quality control according to the methodology recommended by the MGO (Rough and systematic errors of observation were excluded; the 3- $\sigma$ test was used, as well as the Grabs and Moore tests, Kobusheva and Narovlinskiy 1978).

The close arrangement of the stations Bukhta Tikhaya and Krenkel Observatory and the parallel series of observations (1957-1960) make it possible to form a joint (common) homogeneous series (1929 - present, 2017).

\section{Series comparison methods}

It is known that the value ratio of the SAT values even between closely spaced meteorological stations does not remain constant, but depends on the macrocirculation features of a particular region, the period of the year, as well as on individual synoptic situations and local weather anomalies. For example, meteorological stations may be at different distances from the position of the center of large-scale temperature anomalies. The recurrence of synoptic situations can also vary, and microclimatic features of terrain in the area of weather stations may occur. The duration of parallel observations at two neighboring meteorological stations should be at least 6 years to obtain correct regression dependencies (Lobanov et al. 2005). Application of the total (calculated by the average monthly data) regression equation should be recognized as legitimate if short

series of parallel observations are used and when it is impossible to construct the regression equations for each month separately.

In our case, the temporary overlap was only 2 full years (1958 and 1959) and we had two rows of parallel (synchronous) mean daily SAT values (calculated by observation data). In fact, a parallel series of observations was made from November $1^{\text {st }}, 1957$ to February $29^{\text {th }}, 1960$ (28 months). However, the use of additional data (November, December 1957 and January, February 1960) could lead to the fact that the proportion of winter months would increase in compared with other seasons in the obtained regression relationships. Therefore, we took the path of equilibrium (equivalent) presentation of all months in our comparative series. 


\section{The skipping observational data}

The reconstructed series of average annual SAT values (1929-2017) for the weather station Krenkel Observatory are presented in Fig. 3. We used the smoothing of the initial series with a moving average filter (averaging interval of 11 years) in order to more clearly identify the recent warming, excluding the so-called "weather noise", which may prevent the most correct assessment of the onset of this important climatic process. The main idea of using the moving average filter was not so much high-quality filtering (the Gaussian filter is probably more preferable for these purposes), but more clear identification and evaluation of the corresponding warming period. However, the problem of the correct application of this method is related to the gaps in instrumental observation data (2001-2004). Two series of smoothed average annual SAT values were calculated (Fig. 3) The first data set contains data gaps within several 11-year smoothing time intervals, where there are not data for years from 2001 to 2004. The average SAT values for such intervals were calculated from 10,9, 8, and 7 members of the initial series (series A). The reanalysis [Other sources, 5] was used to fill the gaps in the initial data set. The smoothing procedure was repeated for the new series obtained using the reanalysis with the above-mentioned moving average filter (series $\mathrm{R}$ ). The 20thC_ReanV3 reanalysis was used as the longest (starting from the middle of the 19th century) compared to the ERA-Interim/ERA5 reanalysis (from 1979) and the JRA-55 reanalysis (from 1958) (Przybylak and Wyszyński 2020). Nevertheless, we compared the data for the Krenkel Observatory station calculated by the 20thC_ReanV3 and, for example, by ERA-Interim/ERA5 reanalysis for the period starting from 1979. The discrepancies between the series obtained using the indicated reanalysis did not exceed the accuracy of calculating the average monthly SAT estimates. Thus, the use of the 20thC_ReanV3 reanalysis seems to be more preferable in comparison with other approaches.

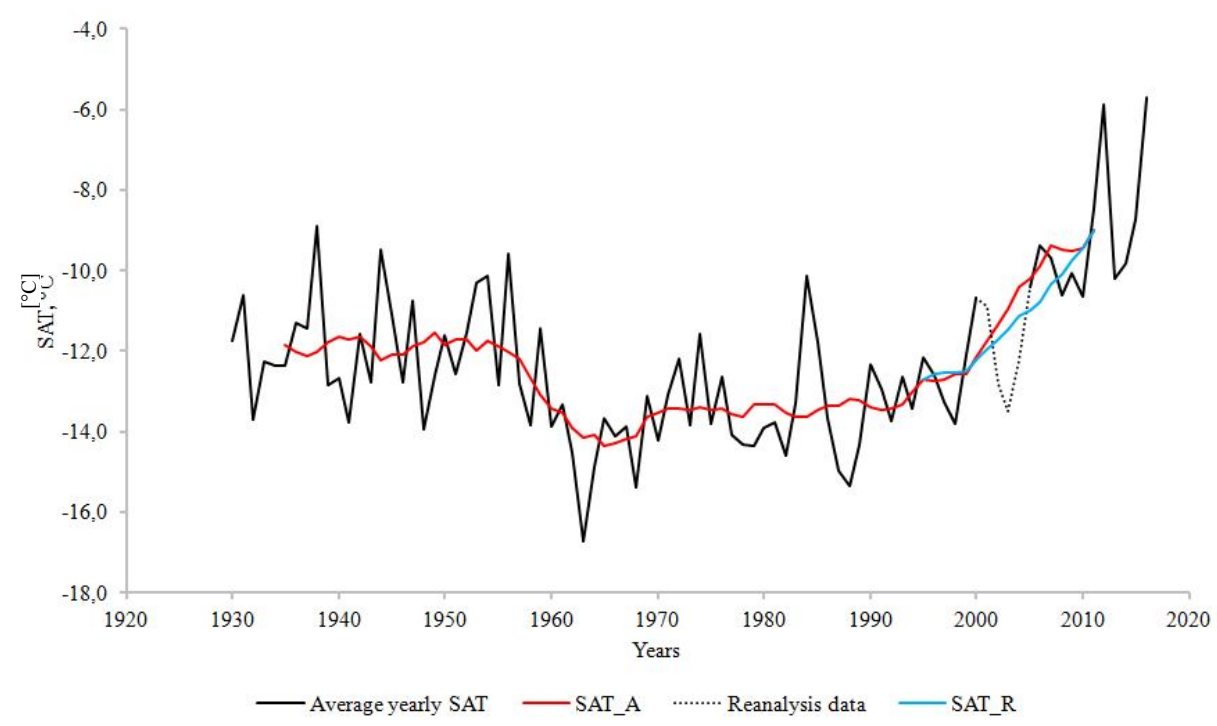

Fig. 3. The annual average SAT values and calculated using the 11-year moving average for the period from 1929 to 2017. 


\section{Results and Discussion}

\section{Creation of composite rows}

We used several approaches to obtain regression dependencies between two data series. Approach 1: we got the linear regression equations (1) for each month separately for 1958 and 1959, using daily average data (Eqn. 1):

$$
\mathrm{Y}=a \mathrm{X}+b \text {, }
$$

where $\mathrm{X}$ - average month SAT at station predictor ("Bukhta Tikhaya"), Y - SAT at weather station "Krenkel Observatory", $a$, $b$ - coefficients.

Then we calculated the average values of the coefficients of the regression equation (" $a$ ") for each conditional month, using the estimates obtained for each individual year $(1958,1959)$. Approach 2: the series of mean daily SAT data for each month of the same name in 1958 and 1959 were combined into one common data set (instead of 30 data points for each month we got a series made up of 60 data points). Next, we got 12 linear regression equations for each month separately. Approach 3: two linear regression equations were calculated, separately for 1958 and 1959, using month average data only, and their comparison was performed. Approach 4: we combined in a single series (analogue of Approach 2) the calculated mean monthly SAT values of each individual year (months of the same name). Thus, a data set of 24 members was analyzed instead of a series of 12 data points like in Approach 1: (for each year individually). We found that the coefficients of the regression equation (1), i.e. $a, b$, obtained for both periods $(1958,1959)$ of parallel operation (Approach 3), coincide in absolute value, which is clearly seen from Fig. 4a.

The linear regression equation calculated in accordance with Approach 4 is presented in Fig. 3b. It is clearly seen that the mean monthly values SAT calculated for each year separately fit well on one straight line, as shown in the Fig. $4 \mathrm{~b}$. With this approach, the regression equation is built on all available mean monthly SAT values (the series consists of 24 data points). In this case, the anomalies of individual months are smoothed out, and the coefficients of the equation are quite stable. There were no statistically significant differences in the coefficients of the individual regression equations linking the mean monthly SAT values in each annual cycle (1958 and 1959). Thus, for the final calculations, Approach 4 was adopted. In our case (relatively short joint series of observations), the use of the general regression equation should be recognized as reasonable.

There are some additional arguments in favor of choosing Approach 4. The parameters of the climate system in the form of average values of a certain characteristic (in our case, SAT) reflect both long-term climatic changes and weather noises for a certain period of averaging. The SAT values averaged over the day contain a significant portion of the weather variability, which can be considered as a random component. This was the main reason why we abandoned the use of daily average data. The both stations were influenced by individual microclimatic conditions. But the influence of the microclimate diminishes when using the daily average values and practically not manifested in the average monthly data. Thus, we have chosen Approach 4 for the calculation (reconstruction) of monthly average SAT values for the Krenkel Observatory for the period 1929-1957.

In this way, we received the longest series of climatic observations based on regular instrumental meteorological observations carried out by the Hydrometeorological Service of Russia in the FJL archipelago (1929-2017). 

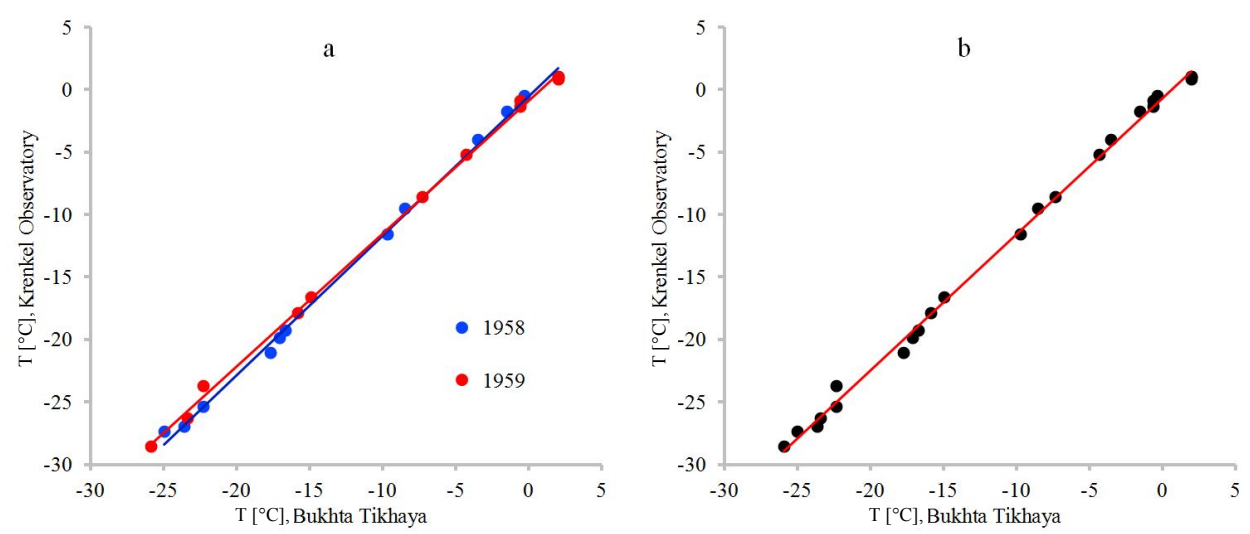

Fig. 4. The linear regression equations calculated on the basis of mean monthly SAT data for each year separately (a) and correlation of mean monthly SAT values at the "Krenkel Observatory" and "Bukhta Tikhaya" stations (b). Note: (a) 1958: $\mathrm{Y}=1.114 \mathrm{X}-0.51\left(R^{2}=0.998\right) ; 1959: \mathrm{Y}=1.063 \mathrm{X}-$ $0.84\left(R^{2}=0.998\right)$; (b) $\mathrm{Y}=1.089 \mathrm{X}-0.71\left(R^{2}=0.997\right)$.

\section{The effect of skipping observational data on the trend estimates calculation}

For the reconstructed series of average annual SAT values (1929-2017) for the weather station Krenkel Observatory, there is a discrepancy between the smoothed average annual values in the $\mathrm{A}$ and $\mathrm{R}$ series, because the reanalysis gives underestimated values (see Fig. 3). However, the effect of data gaps extends along the time series in both directions from the period 2001-2004, when smoothing the initial series with a moving average. This interval is 12-14 years depending on the month (see Table 1).

The errors in the calculation of the smoothed SAT values for series A and R were estimated by their standard deviations (SD). SD of the smoothed SAT values were calculated from 11 pairs of values (Eqn. 2):

$$
\sigma_{i}=\sqrt{\frac{\sum_{i-5}^{i+5}\left(y-y^{\prime}\right)^{2}}{11}}
$$

where $y-$ initial SAT values, $y^{\prime}-\mathrm{SAT}$ values smoothed by 11 -year filter, $i$ - year.
SD were calculated from $10,9,8$, and 7 pairs of $y$ and $y^{\prime}$ values for 11-year time intervals containing data gaps. SD of the smoothed values calculated over 11-year time intervals were limited by 2006 or 2007 since the smoothed SAT values are limited by 2011 or 2012 (see Table 1). The interval of influence of data gaps extends from 1996 to 2009 for the average annual smoothed SAT values. The smoothed values of SAT, SD and, accordingly, confidence intervals for series $A$ and $R$ coincide until 1996 (see Fig. 5). The coincidence of the smoothed SAT values is observed after 2009 , because SD of the smoothed average annual SAT are limited by 2006.

A comparison of the maximum and minimum SD values calculated for the smoothed average monthly SAT values (see Fig. 6) shows that they (SD values for the period 1996-2007) do not go beyond the limits of similar indicators for series without data gaps (1939-1995). 
B. IVANOV et al.

\begin{tabular}{|c|c|c|c|c|}
\hline \multirow{2}{*}{$\begin{array}{c}\text { Time } \\
\text { interval }\end{array}$} & \multicolumn{2}{|c|}{ Initial data } & \multirow{2}{*}{$\begin{array}{c}\text { Calculated } \\
\text { Smoothed } \\
\text { SAT }\end{array}$} & \multirow{2}{*}{$\begin{array}{c}\text { Interval of influence } \\
\text { of gaps in the source } \\
\text { data }\end{array}$} \\
\hline & Available & Absent & & \\
\hline $\begin{array}{c}\text { January } \\
\text { February } \\
\text { March } \\
\text { April } \\
\text { May } \\
\text { June } \\
\text { July } \\
\end{array}$ & $1930-2017$ & \multirow[t]{3}{*}{$2002-2004$} & $1935-2012$ & \multirow[t]{3}{*}{$1997-2009$} \\
\hline August & $1930-2016$ & & $1935-2011$ & \\
\hline September & \multirow{3}{*}{$1929-2016$} & & \multirow{3}{*}{$1934-2011$} & \\
\hline October & & 2001-2004 & & 1996-2009 \\
\hline $\begin{array}{l}\text { November } \\
\text { December }\end{array}$ & & $2002-2003$ & & $1997-2008$ \\
\hline
\end{tabular}

Table 1. Time intervals for the available initial and smoothed average monthly and annual average SAT.

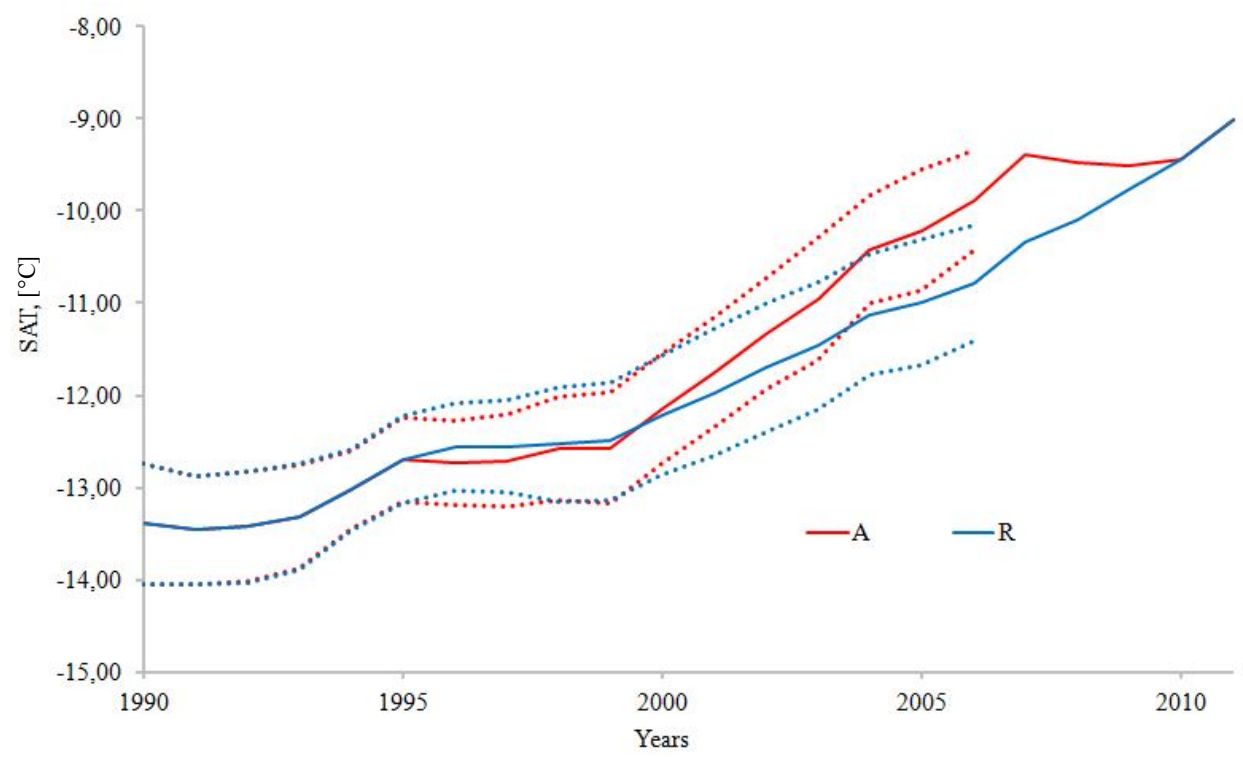

Fig. 5. Average annual SAT values smoothed with an 11-year filter with a $95 \%$ confidence band for the period 1990-2011. 


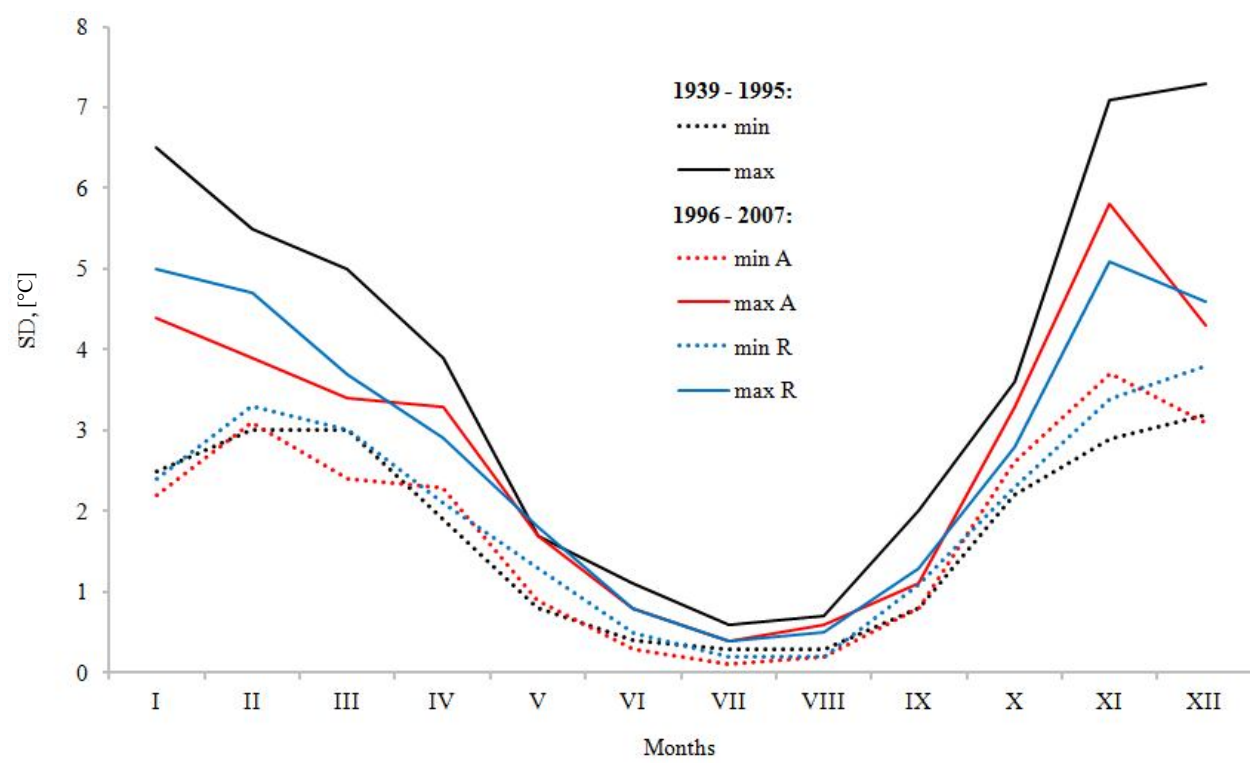

Fig. 6. The maximum and minimum SD of the smoothed average monthly SAT values for periods without data gaps (black color curve), with data gaps (red color curve); gaps filled by reanalysis data (blue color curve).

A comparison of the mean values of the $\mathrm{SD}$ of the smoothed monthly and annual average SAT values (series A and R) was carried out using Students t-test for conjugate pairs of observations (Rozhkov 2002). The mean SD values of series A are smaller than similar estimates for series $\mathrm{R}$ for 8 months and the whole year, with a significance level of $P<0.05$. The mean SD values of series $A$ are greater than similar estimates for series $\mathrm{R}$ for 4 months. Comparison of rows $\mathrm{A}$ and $\mathrm{R}$ shows that the rows do not contradict each other. SD calculation results for series A and $\mathrm{R}$ are consistent with each other, but the error in calculating the smoothed SAT values of series

\section{Summary of the most important results}

Anomalies in the mean annual SAT values calculated relative to the average SAT values for the entire observation period (1929-2017) and anomalies calculated us-
A is generally lower than that of series $\mathrm{R}$.

In our study, the features of warming in the archipelago are analyzed using the original data series (unsmoothed). Smoothed series obtained using various filtration procedures are used only to identify the most general long-term trends, as well as to more accurately determine the onset of certain transitional climatic processes, for example, recent warming. The current study of warming in the archipelago was carried out using the initial series of monthly average data that have gaps in the period 2001-2004 (A) and the series where the gaps are filled using reanalysis 20thC_ReanV3 reanalysis ( $R$ ).

ing the 11-year moving average are presented in Fig. 7. Sustainable increase in the average annual SAT values has been observed since the 1990s, and a stabile 
transition of the SAT anomalies through zero has been observed since the beginning of this century (2000s). The onset of recent warming in FJL is in good agreement with the increase in SAT recorded in the Arctic basin since the 1990s (Alekseev et al. 2015, Bekryaev et al. 2010). Linear trend indicators are calculated for two periods: $1990-2017$ and 2000-2017, respectively. Corresponding estimates of the coefficients of linear trends are presented in Fig. 8 and Table 2.

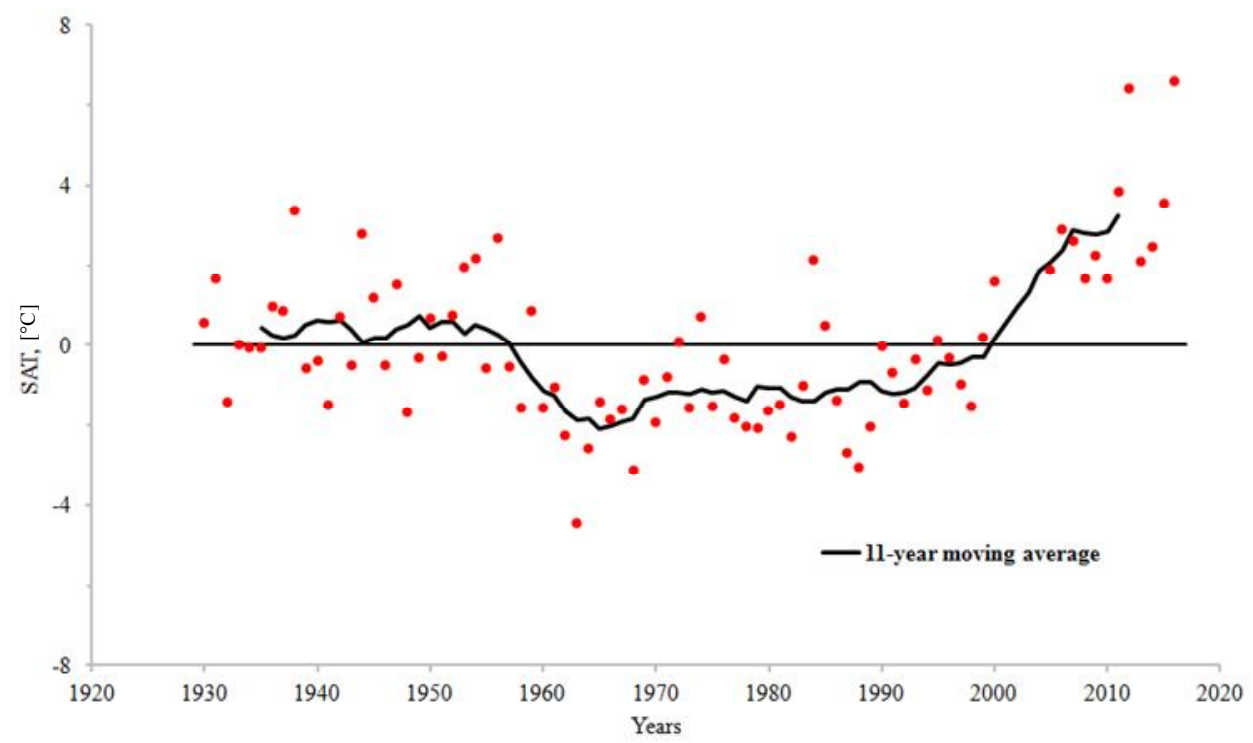

Fig. 7. Changes in the average annual values of the SAT anomalies for the period from 1929 to 2017 (red dots) and the SAT anomalies calculated using the 11-year moving averaging (black curve).
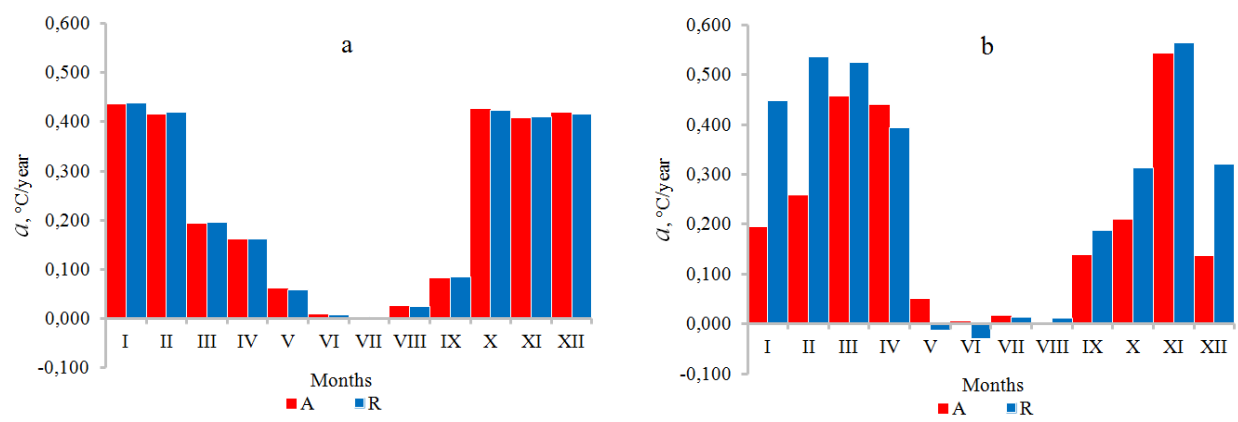

Fig. 8. Coefficients of linear trends " $a$ " of monthly average SAT values for periods of "modern" warming in 1990-2017 (a) and 2000-2017 (b). Note: A - with gaps, $\mathbf{R}$ - with reanalysis data. 
As follows from the presented Table 2, the characteristics of the linear trends of the monthly and annual average SAT values for both series (1990-2017) are similar. Signs of linear trends in series A and $\mathrm{R}$ are positive, the greatest warming is observed from October to February, and the smallest from June to August. Linear trends for the annual and all monthly series except June and July are statistically significant at the $P<0.20$ level. The increase in the average annual SAT values is 6.3 and $6.2^{\circ} \mathrm{C}$ for series $\mathrm{A}$ and $\mathrm{R}$, respectively, for the period 1990-2017.

However, for a shorter period of 2000 2017, data gaps in 2001-2004 led to a significant difference in the characteristics of linear trends in the monthly average and average annual SAT of series A and R. For example, the signs of linear trends in the $\mathrm{A}$ and $\mathrm{R}$ series for the year and all months exept May and June are the same and positive. The trend is positive for series $\mathrm{A}$ and negative for series $\mathrm{R}$ in May and June. The greatest warming for series $\mathrm{A}$ is observed in March-April and November, and from October to April for series R. The least warming for series $\mathrm{A}$ is seen from June to August, and from May to August for series R. The statistical significance of the linear trends in series $\mathrm{A}$ in this shorter period (2000-2017) is relatively small: linear trends are statistically significant at the $P<0.25$ level for March, April, September-November and the annual series. Linear trends are statistically insignificant for the remaining months (January, February, May-August, December). Linear trends of the $\mathrm{R}$ series are statistically significant at the $P<0.15$ level for September-April and the annual series. Linear trends for the remaining months (May-August) are statistically insignificant. Finally, the increase in the average annual SAT values for $2000-2017$ is 3.8 and $5.2^{\circ} \mathrm{C}$ for series $\mathrm{A}$ and $\mathrm{R}$, respectively.

\begin{tabular}{|c|c|c|c|c|c|c|c|c|c|c|c|c|}
\hline \multirow{3}{*}{ Month } & \multicolumn{6}{|c|}{ 1990-2017 } & \multicolumn{6}{|c|}{$2000-2017$} \\
\hline & \multicolumn{3}{|c|}{$\begin{array}{l}\text { With gaps within } \\
\text { reanalysis } \\
2001-2004(A)\end{array}$} & \multicolumn{3}{|c|}{$\begin{array}{c}\text { The gaps are filled } \\
\text { by within re- } \\
\text { analysis data }(R)\end{array}$} & \multicolumn{3}{|c|}{$\begin{array}{l}\text { With gaps within } \\
\text { reanalysis } \\
\text { 2001-2004 (A) }\end{array}$} & \multicolumn{3}{|c|}{$\begin{array}{c}\text { The gaps are filled } \\
\text { by within re- } \\
\text { analysis data }(R)\end{array}$} \\
\hline & $a$ & $R^{2}$ & $P<$ & $a$ & $R^{2}$ & $P<$ & $a$ & $R^{2}$ & $P<$ & $a$ & $R^{2}$ & $P<$ \\
\hline I & 0.436 & 0.47 & 0.05 & 0.439 & 0.43 & 0.05 & 0.193 & 0.06 & 0.40 & 0.448 & 0.21 & 0.10 \\
\hline II & & & 0.0 & & & 0.05 & & & 30 & 0.537 & & 0.05 \\
\hline III & & & 0.05 & & & 0.05 & & 28 & 0 . & 525 & & 0.05 \\
\hline IV & 162 & 13 & 0.10 & 0.162 & 0.13 & 0.10 & 0.440 & 0.34 & 0.05 & 0.393 & 0.34 & 0.05 \\
\hline $\mathrm{V}$ & & & 15 & & & 20 & & 03 & 0.55 & 012 & 0 & 0.90 \\
\hline VI & & & 0.65 & & 0.01 & 0.70 & 0.0 & 0.00 & 0.90 & 029 & 0.05 & 0.40 \\
\hline VII & 004 & 01 & 0.75 & 0.004 & 0.01 & 0.70 & 0.016 & 0.05 & 0.45 & 0.014 & 0.04 & 0.45 \\
\hline VIII & & 0.14 & 0.10 & 0.025 & 0.13 & 0.10 & 0.001 & 0.00 & 0.99 & 0.012 & 0.02 & 0.65 \\
\hline IX & 2 & 0.3 & 0.05 & 0.085 & 0.2 & 0.05 & 0.139 & 0.28 & 0.10 & 0.187 & 0.37 & 0.05 \\
\hline $\mathrm{X}$ & 27 & 0.6 & 0.05 & 0.423 & 0.64 & 0.05 & 0.209 & 0.13 & 0.25 & 0.313 & 0.30 & 0.05 \\
\hline XI & 408 & 0.33 & 0.05 & 0.410 & 0.32 & 0.05 & 0.543 & 0.23 & 0.10 & 0.564 & 0.30 & 0.05 \\
\hline XII & & & 0.05 & 0.416 & 0.39 & 0.05 & 0.135 & 0.03 & 0.60 & 0.321 & 0.14 & 0.15 \\
\hline Year & 0.224 & 0.72 & 0.05 & 0.223 & 0.66 & 0.05 & 0.211 & 0.32 & 0.05 & 0.289 & 0.50 & 0.05 \\
\hline$\Delta T$ & 6.3 & & & 6.2 & & & 3.8 & & & 5.2 & & \\
\hline
\end{tabular}

Table 2. Characteristics of linear trends of initial average monthly and annual average SAT values for the periods of "modern" warming 1990-2017, 2000-2017. " $a$ " - is the trend line coefficient $\left({ }^{\circ} \mathrm{C} /\right.$ year $) ; R^{2}$ - the coefficient of determination; $P$ - level of statistical significance; $\Delta T$ - total warming $\left({ }^{\circ} \mathrm{C}\right)$. 
Thus, the linear trends in the monthly and annual mean values of SAT of series $\mathrm{A}$ and $\mathrm{R}$ for the period 1990-2017 are similar, while for the period 2000-2017 they differ significantly. At the same time, the statistical significance of the linear trends of the $\mathrm{R}$ series are more convincing than for the A series.

Missing data (2001-2004) led to a discrepancy between the smoothed values of the A and R series in the 1996-2009 period (see Fig. 4). Nevertheless, it insignificantly affected the linear trend indicators calculated for the entire observation period using the original data (1929-2017). The corresponding estimates of the coefficients of linear trends $a$ are presented in Fig. 9.

The characteristics of the linear trends of the A and R series in the period 19962009 are in good agreement with each other. Signs of linear trends of monthly averages coincide for both series for all months. Trends are positive (except for December). The most remarkable warming was observed in March and April, the least
- in June-August. The statistical significance of the trends also has common features for both series (see Table 3).

Trends are statistically significant at the $P<0.05$ level for March-June, September and the annual series. Trends are statistically insignificant for January-February, July and October-December. The absolute values of the coefficients $a$ differ insignificantly for both series. The largest discrepancies are observed in January and February, but for these months the trends are statistically insignificant. The overall increase in the mean annual SAT values was 1.8 and $1.6^{\circ} \mathrm{C}$ for series $\mathrm{A}$ and $\mathrm{R}$, respectively, for the entire observation period (1929-2017). As follows from Table 3, the characteristics of the trends of both series, calculated for the monthly and annual average SAT values, are in good agreement with each other in absolute value and sign. This allows us to carry out subsequent calculations of similar characteristics (f.e. for the selected natural seasons of the year) based only on series A.

\begin{tabular}{|c|c|c|c|c|c|c|}
\hline \multirow{2}{*}{ Month } & \multicolumn{3}{|c|}{ Series A } & \multicolumn{3}{c|}{ Series R } \\
\cline { 2 - 7 } & $\boldsymbol{a}$ & $\boldsymbol{R}^{\mathbf{2}}$ & $\boldsymbol{P}<$ & $\boldsymbol{a}$ & $\boldsymbol{R}^{\mathbf{2}}$ & $\mathbf{P}<$ \\
\hline I & 0.023 & 0.010 & 0.40 & 0.017 & 0.005 & 0.50 \\
\hline II & 0.028 & 0.016 & 0.30 & 0.019 & 0.008 & 0.45 \\
\hline III & 0.060 & 0.114 & 0.05 & 0.055 & 0.097 & 0.05 \\
\hline IV & 0.039 & 0.083 & 0.05 & 0.039 & 0.087 & 0.05 \\
\hline V & 0.022 & 0.103 & 0.05 & 0.026 & 0.132 & 0.05 \\
\hline VI & 0.008 & 0.071 & 0.05 & 0.010 & 0.098 & 0.05 \\
\hline VII & 0.002 & 0.010 & 0.40 & 0.002 & 0.009 & 0.40 \\
\hline VIII & 0.004 & 0.032 & 0.15 & 0.004 & 0.032 & 0.10 \\
\hline IX & 0.023 & 0.152 & 0.05 & 0.021 & 0.132 & 0.05 \\
\hline X & 0.013 & 0.007 & 0.50 & 0.013 & 0.008 & 0.45 \\
\hline XI & 0.027 & 0.015 & 0.30 & 0.025 & 0.014 & 0.30 \\
\hline XII & -0.003 & 0.000 & 0.95 & -0.004 & 0.000 & 0.90 \\
\hline Year & 0.020 & 0.060 & 0.05 & 0.018 & 0.054 & 0.05 \\
\hline$\Delta$ T & \multicolumn{3}{|c|}{1.8} & \multicolumn{3}{c|}{1.6} \\
\hline
\end{tabular}

Table 3. Characteristics of linear trends of monthly average and annual average SAT values for the period 1929-2017. Note: $a-$ is the trend line coefficient $\left({ }^{\circ} \mathrm{C} /\right.$ year); $R^{2}-$ is the coefficient of determination; $P-$ is the level of statistical significance, $\Delta T$ - total warming. 


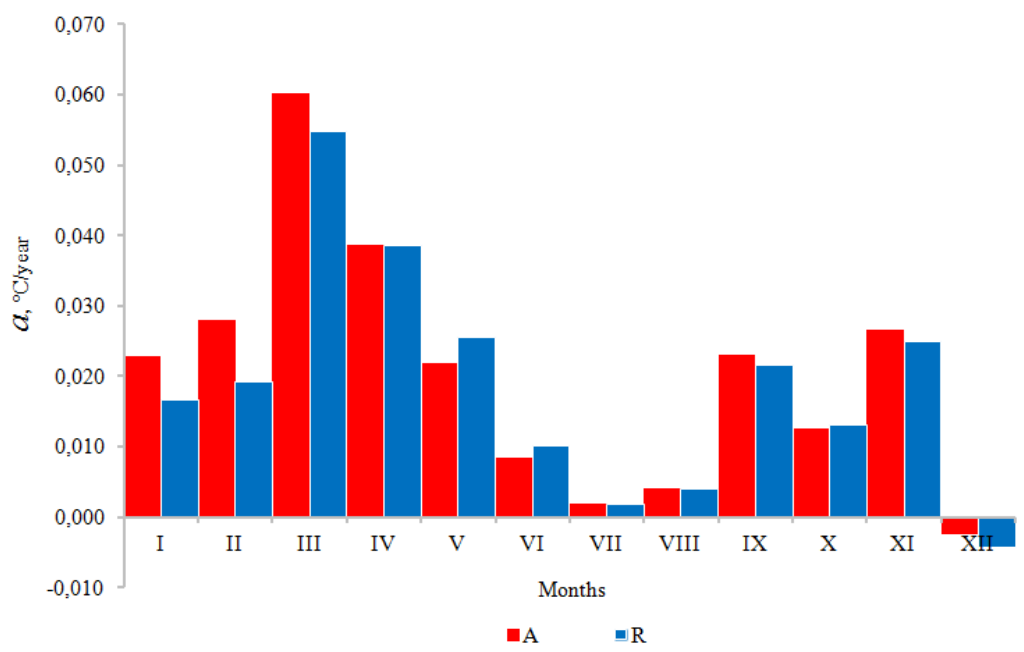

Fig. 9. Linear trend coefficients " $a$ " of monthly average SAT values (1929-2017) calculated for series with gaps $(\mathrm{A})$ and for series in which gaps are filled by reanalysis data $(\mathrm{R})$.

Quantitative estimates of the long-term variability of the SAT and its absolute monthly mean values make it possible to more accurately identify the characteristic (natural) seasons of the year. In our case, a season is considered a period of time of the year during which the value of the long-term SAT variability remains constant. The first approximation, the longterm distributions of the monthly mean SAT values differ in the character of variability: in the winter months it is more, in the summer months it is less (see Fig. 10). The absolute SAT values also varied widely for individual months.

Average long-term SAT values calculated for the entire observation period (1929-2017) were chosen as quantitative SAT indicators for each month separately. The estimates of the standard deviations (SD), calculated from the monthly mean SAT values for the period 1929-2017, were used as a quantitative measure of longterm variability. We carried out a joint statistically grouped the SAT and SD values using the following criteria. Average annual SAT estimates calculated for each month vary in a wide range of values from
-22.5 to $+0.7^{\circ} \mathrm{C}$. We have divided this range into three groups: low SAT values (from -25 to $-15^{\circ} \mathrm{C}$ ), medium (from -15 to $-5^{\circ} \mathrm{C}$ ), and high (from -5 to $+1^{\circ} \mathrm{C}$ ). In turn, the SD estimates calculated for each month varied from 0.5 to $5.8{ }^{\circ} \mathrm{C}$. We have also divided this range into three groups: $0-2$, $2-4,4-6^{\circ} \mathrm{C}$. Thus, we managed to distribute all calendar months over the next natural seasons of the year (see Table 4).

Figs. 11 and 12 show a graphical interpretation (visualization) of the distribution of calendar months by natural seasons of the year.

We still attribute April to the winter season, although it differs from the winter months (November-March) in terms of SD. The SAT values are still low in April, but the SD (variability) values are decreasing. Indirect confirmation of our conclusion is that the snow cover of the archipelago in April, as a rule, is not yet melting, which is typical for spring (May).

Smoothed SAT data gives a good visualization of the distribution of calendar months by natural seasons of the year (see Fig. 12). 


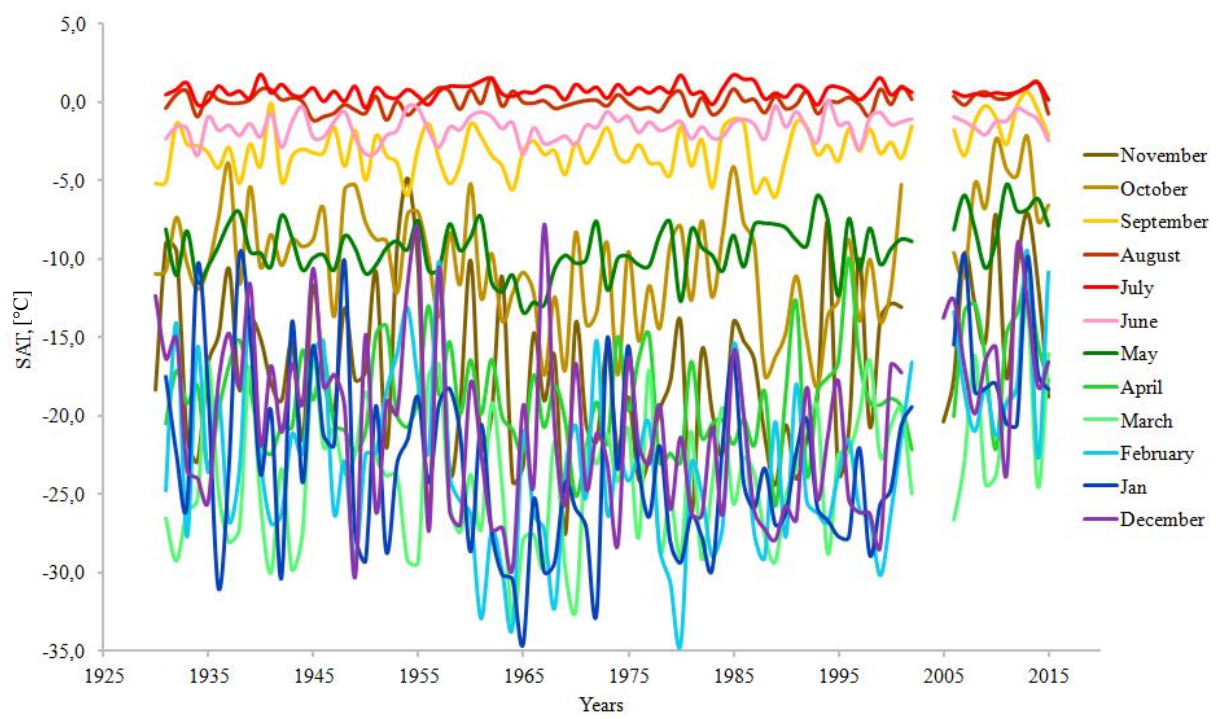

Fig. 10. Monthly average SAT values (1929-2017).

The lowest absolute SAT values and its significant variability (SD) are typical for the winter season of the year (NovemberApril). SAT remains low, but its variability (SD) decreases at the end of winter (April). The absolute SAT values significantly increase in spring (May), but its variability decreases. The highest SAT values are observed in the summer (JuneSeptember), while their variability is low.
Finally, the absolute SAT values decrease in autumn (October), and its variability increases during this period.

Thus, the natural seasons of the year and their duration are highlighted on the basis of simple statistical criteria. Summer and winter are the longest seasons. They last 4 and 6 months, respectively. The shortest seasons are autumn and spring. Their duration is one month.

\begin{tabular}{|c|c|c|c|}
\hline${\mathrm{SAT},\left[{ }^{\circ} \mathrm{C}\right]}^{\mathrm{SD},\left[{ }^{\circ} \mathrm{C}\right]}$ & $0-2$ & $2-4$ & $4-6$ \\
\hline$-5 /+1$ & $\begin{array}{c}\text { June } \\
\text { July } \\
\text { August } \\
\text { September }\end{array}$ & & \\
\hline$-15 /-5$ & May & October & \\
\hline$-25 /-15$ & & April & $\begin{array}{c}\text { November } \\
\text { December } \\
\text { January } \\
\text { February } \\
\text { March }\end{array}$ \\
\hline
\end{tabular}

Table 4. Distribution of all calendar months over the natural seasons of the year. 


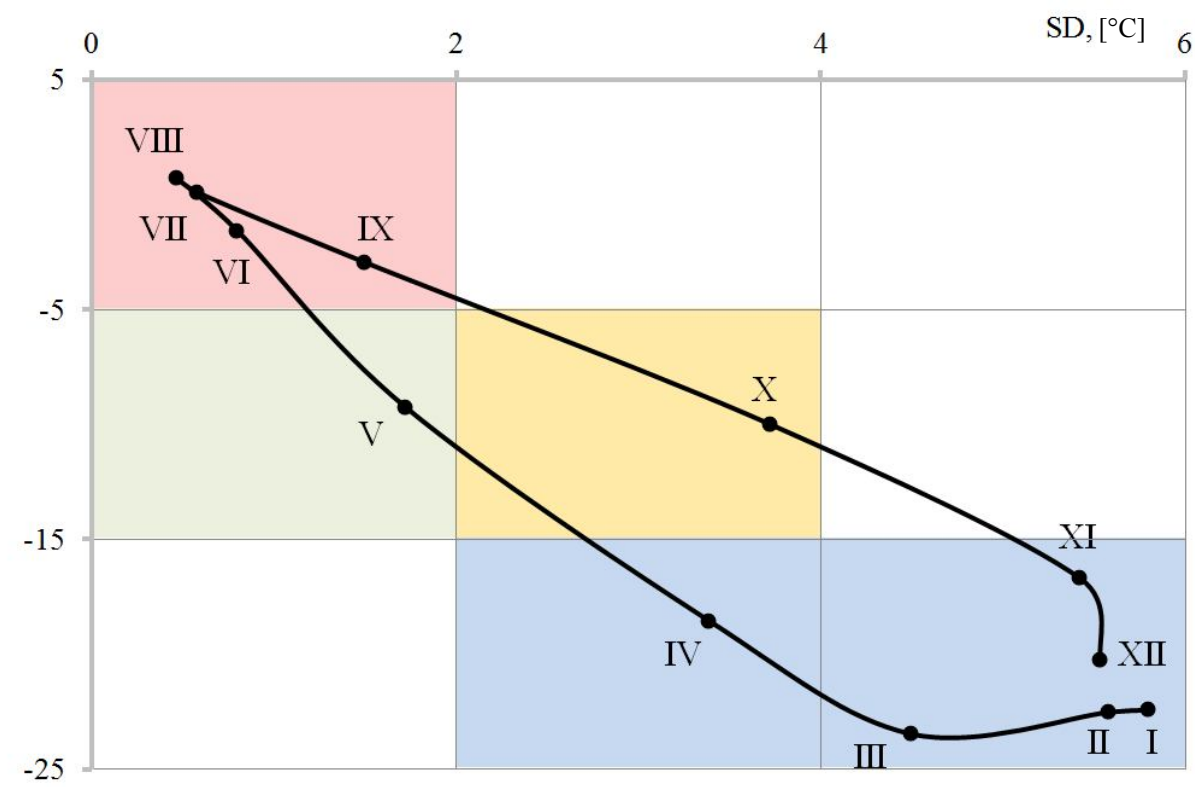

$\mathrm{SAT},\left[{ }^{\circ} \mathrm{C}\right]$

Fig. 11. Distribution of all calendar months over the natural seasons of the year.

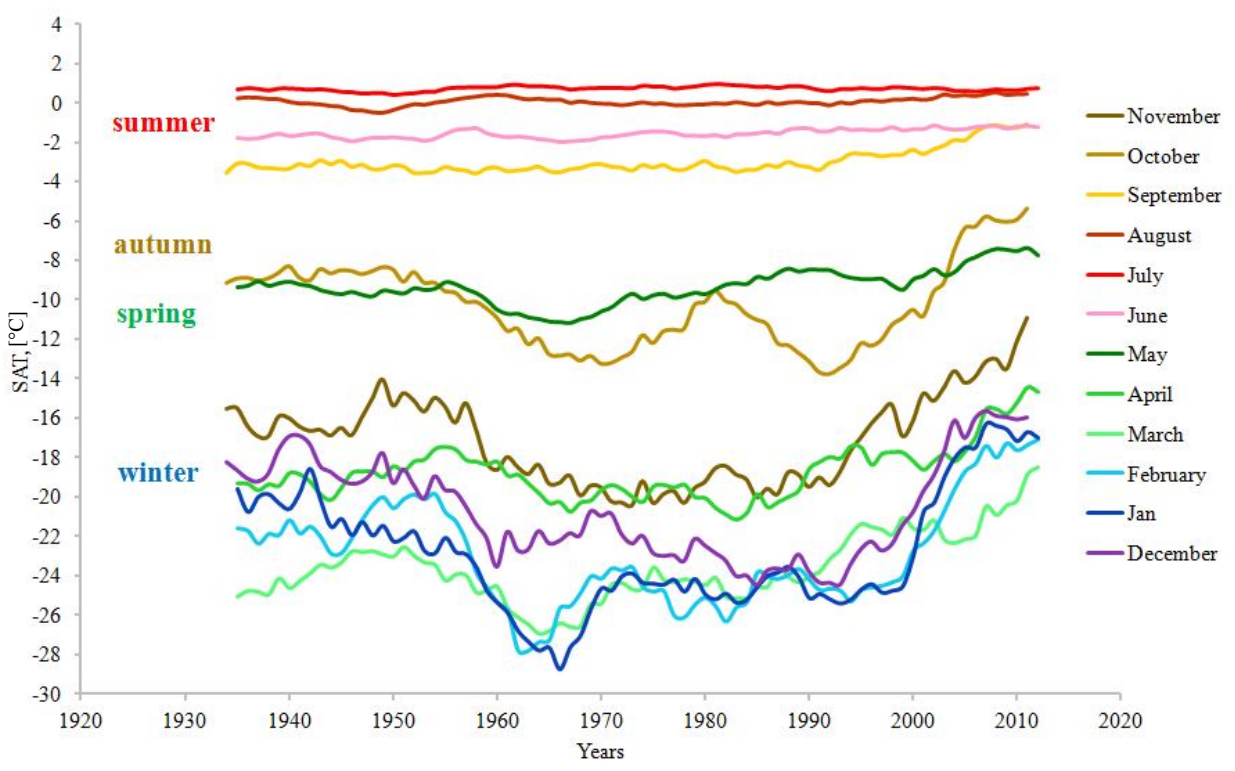

Fig. 12. Monthly average SAT values (smoothed data for period 1934-2012). 
The character of the long-term variability of the mean monthly SAT values persists during almost the entire period of regular instrumental observations (Figs. $10,12)$. Estimates of the average, maximum, minimum values of SAT and SD for the period 1929-2017 are in good agreement with the estimates of other authors. For example, similar results were obtained for the periods 1881-1904 (Wiese 1930), 1952-1980 (Jenyuk 2014), 1961-1990 (Krenke 1996). In these studies, a high interannual variability of average monthly winter temperatures is noted as compared to summer ones. According to Wiese (1930), there are only three seasons in FJL: winter (October-April), spring (May), summer (June-September).

The characteristics of linear trends calculated for the selected natural seasons both for the entire observation period and for the selected periods of recent warming are presented in Table 5. Linear trend char- acteristics for all three periods are positive. For the entire observation period, the greatest warming was observed in winter and spring, and the smallest in summer and autumn. For both identified periods of recent warming, the greatest warming was observed in winter and autumn, and the smallest in the spring and summer. At the same time, the rate of warming in winter is an order of magnitude higher than in summer: 0.326 against 0.028 for the period 19902017 and 0.284 against 0.034 for the period 2000-2017. Seasonal linear trends for the entire observation period are significant at the $\mathrm{P}<0.05$ level, with the exception of a statistically insignificant autumn trend. All seasonal linear trends for the period 1990-2017 are statistically significant at the $\mathrm{P}<0.15$ level. Seasonal linear trends for the period 2000-2017 are significant at the $\mathrm{P}<0.25$ level, except for a statistically insignificant linear trend in the spring season.

\begin{tabular}{|c|c|c|c|c|c|c|c|c|c|}
\hline & \multicolumn{3}{|c|}{$\mathbf{1 9 2 9 - 2 0 1 7}$} & \multicolumn{3}{c|}{$\mathbf{1 9 9 0 - 2 0 1 7}$} & \multicolumn{3}{c|}{$\mathbf{2 0 0 0 - 2 0 1 7}$} \\
\cline { 2 - 10 } & $\begin{array}{c}\boldsymbol{a}, \\
{ }^{\circ} \mathbf{C} / \text { year }\end{array}$ & $\boldsymbol{R}^{\mathbf{2}}$ & $\boldsymbol{P}<$ & $\begin{array}{c}\boldsymbol{a} \\
{ }^{\circ} \mathbf{C} / \text { year }\end{array}$ & $\boldsymbol{R}^{\mathbf{2}}$ & $\boldsymbol{P}<$ & $\begin{array}{c}\boldsymbol{a}, \\
{ }^{\circ} \mathbf{C} / \text { year }\end{array}$ & $\boldsymbol{R}^{\mathbf{2}}$ & $\boldsymbol{P}<$ \\
\hline Winter & 0.030 & 0.052 & 0.05 & 0.326 & 0.663 & 0.01 & 0.284 & 0.236 & 0.10 \\
\hline Spring & 0.022 & 0.103 & 0.05 & 0.061 & 0.094 & 0.15 & 0.051 & 0.029 & 0.55 \\
\hline Summer & 0.009 & 0.157 & 0.01 & 0.028 & 0.196 & 0.05 & 0.034 & 0.112 & 0.25 \\
\hline Autumn & 0.013 & 0.007 & 0.50 & 0.427 & 0.667 & 0.05 & 0.209 & 0.129 & 0.25 \\
\hline
\end{tabular}

Table 5. Characteristics of linear trends for the selected seasons, calculated from the initial data

\section{Conclusions}

The main conclusions that follow from our preliminary study are presented below:

(1) The mean annual surface air temperature (SAT) increase was $1.6-1.8^{\circ} \mathrm{C}$ for the entire available period of instrumental observations (1929-2017) in the Franz Joseph Land archipelago;

(2) Greatest SAT increase was observed in March-April with $0.6^{\circ} \mathrm{C} /$ decade;

(3) The recent warming at the Franz Joseph Land has been observed since the $1990 \mathrm{~s}$. The SAT increase was $6.3^{\circ} \mathrm{C}$ for the period $1990-2017$ and $5.2^{\circ} \mathrm{C}$ for the period 2000-2017;

(4) For the period 1990-2017 the greatest warming was observed in October to February with $4.4^{\circ} \mathrm{C} /$ decade;

(5) For the period 2000-2017 the greatest warming was observed in January to April and in November to December with $5.6^{\circ} \mathrm{C} /$ decade;

(6) The main nature seasons of the year are winter (November-April), spring (May), summer (June-September) and au- 
tumn (October);

(7) The main contribution to the overall warming in the archipelago over the entire observation period was made by the winter season. However, during the period of modern warming (1990-2017), this role is already played by two seasons - winter and autumn.

\section{References}

Aleksandrov, E. I., Bryazgin, N. N., Forland, E. J., Radionov, V. F. and Svyashchennikov, P. N. (2005): Seasonal, interannual and long-term variability of precipitation and snow depth in the region of the Barents and Kara seas. Polar Research, 24: 69-85

Aleksandrov, E. I., Radionov, V. F. and SviashchenNikov, P. N. (2003): The height of the snow cover and its changes in the waters of the Barents and Kara Seas. Trudy Arkticheskogo $i$ antarkticheskogo nauchno-issledovatel'skogo instituta [AARI Proceedings], 446: 99-118. (In Russian).

Alekseev, G. V. (2015): Development and amplification of global warming in the Arctic. Fundamantalnaya y prikladnaya klimatologiya [Fundamental and Applied Climatology], 1: 1126. (In Russian).

Alisov, B. P., Drozdov, O. A. and Rubinshtein, E. S. (1952): Climatology course, part 1, 2. Hydrometeoizdat, Leningrad, USSR, 1952, 487 p. (In Russian).

ARAZNY, A., WyszYNSKI, P. and PRZYBYlaK, R. (2019): A comparison of bioclimatic conditions on Franz Josef Land (the Arctic) between the turn of the nineteenth to twentieth century and present day. Theory of Applied Climatology, 137: 2623-2638

Bekryaev, R. V., Polyakov, I. V. and Alekseev, V. A. (2010): Role of polar amplification in long-term surface air temperature variations and modern arctic warming. Journal of Climate, 23: 3888-3906.

Burova, L. P. (1988): Modern changes of integral atmospheric moisture content. Arctic Climate Monitoring. Hydrometeoizdat, Leningrad, USSR, 1988, 69-87. (In Russian).

Burova, L. P. (2000): Long-term changes in the integrated atmospheric moisture content of the Arctic. Trudy Arkticheskogo i antarkticheskogo nauchno-issledovatel'skogo instituta [AARI Proceedings], 440: 29-42. (In Russian).

Bryzgin, N. N., VoskreSENSKIY, A. I. (2000): Atmospheric precipitation in the Russian Arctic. Trudy Arkticheskogo $i$ antarkticheskogo nauchno-issledovatel'skogo instituta [AARI Proceedings], 440: 102-121. (In Russian).

Drozdov, O. A., Vasiliev, V. A., Kobusheva, N. V., Raevskiy, A. N., Smekalova, L. K. and SHKOLNIK, E. P. (1989): Climatology. Hydrometeoizdat, Leningrad, USSR, 1989: 567 p. (In Russian).

JenYuK, S. L. (2014): Climate-forming factors and climatic features of Franz Josef Land. Trudy Kol'skogo nauchnogo centra RAN [Proceeding of Kola science Center], 4(23): 61-69 (In Russian).

IvANOV, B. V. (2019): Comparing the «earlier» and the «modern» warming in West Arctic on example of Svalbard. IOP Conference Series: Earth and Environmental Science. Turbulence, Atmosphere and Climate Dynamics, 231: 012023.

GaVRILOVA, M. K. (1963): Radiation climate of Arctic. Hydrometeoizdat, Leningrad, USSR, 225 p. (In Russian).

Gjelten, H., Nordli, Ø., Isaksen, K., Førland, E., Sviashchennikov, P., Wyszynski, P., Prokhorova, U., Przybylak, R., Ivanov, B. and Urazgildeeva, A. (2016): Air temperature variations and gradients along the coast and fjords of western Spitsbergen. Polar Research, 35: 29878.

KobusheVA, N. V., NAROVlyanSKIY, G. I. (1978): Climatological processing of meteorological information. Hydrometeoizdat, Leningrad, USSR, 295 p. (In Russian). 
KRENKE, A. N. (1996): Franz Josef Land climate. Izvestiya vysshih uchebnyh zavedenij. Geodeziya $i$ aerofotos"emka [Proceedings of higher educational institutions. Geodesy and aerial photography], 3: 48-58 (In Russian).

Lobanov, V. A., Jiltsova, H. L. and Lemeshro, N. A. (2005): Restoration of long-term series of air temperature in the European territory of Russia. Meteorology and Hydrology, 2: 5-14. (In Russian).

Marshunova, M. S., Pimanova, J. E. and Lubo-Lesnichenko, K. E. (2000): The influence of cloudiness on the radiation regime in the Arctic. Trudy Arkticheskogo $i$ antarkticheskogo nauchno-issledovatel'skogo instituta [AARI Proceedings], 440: 137-157. (In Russian).

MoskaL, T. N. (1972): On the tightness of the relationship between the monthly average air temperature at polar stations in the Franz Josef Land region. Trudy Arkticheskogo $i$ antarkticheskogo nauchno-issledovatel'skogo instituta [AARI Proceedings], 307: 119-120. (In Russian).

Nordl, Ø., WyszyŃski, P., GJelten, H. M., IsAKsen, K., ŁupikAsza, E., Niedźwiedź, Y. and PRZYBYLAK, R. (2014): Revisiting the extended Svalbard Airport monthly temperature series, and the compilation of a corresponding daily series 1898-2018. Polar Research, 33: 21349.

PrZYBYlaK, R., Vizi, Z. and WysZYNSKi P. (2010): Air temperature changes in the Arctic from 1801 to 1920. International Journal of Climatology, 30: 791-812.

PRZYBYLAK, R., WYSZYŃSKI, P. (2020): Air temperature changes in the Arctic in the period 19512015 in the light of observational and reanalysis data. Theoretical and Applied Climatology, 139: 75-94. https://doi.org/10.1007/s00704-019-02952-3

Przybylak, R., Wyszynski, P., Vizi, Z. and Jankowska, J. (2012): Atmospheric pressure changes in the Arctic from 1801 to 1920. International Journal of Climatology, 33(7): 17301760.

PRZYBYLAK, R. (2000): Temporal and spatial variation of surface air temperature over the period of instrumental observations in the Arctic. International Journal of Climatology, 20: 587-614.

RADIONOV, V. F. (1997): Scientific-applied reference on the climate of Russia (Arctic region). Solar radiation. Hydrometeoizdat, Saint-Petersburg, Russia, 230 p. (In Russian).

Rozhкov, V.A. (2002): Theory and methods of statistical estimation of probabilistic characteristics of random variables and functions with hydrometeorological examples. Hydrometeoizdat, Saint-Petersburg, Russia, 780 p. (In Russian).

Shapkin, B. S., Rubchenia, A. V., Ivanov, B. V., Revina, A. D. and Bogryantsev, M. V. (2021): Long-term changes in ice coverage in the area of the Svalbard (Spitsbergen) and Franz Josef Land archipelagos. Lyod $i$ Sneg [Ice and Snow], 61(1): 128-136.

WIESE, V. (1930): Franz Josef Land climate. Trudy Instituta po Izucheniyu Severa [Proceeding of Institute of Polar Research], 4: 74-92 (In Russian).

\section{Web sources / Other sources}

[1] https://en.wikipedia.org/wiki/Franz_Josef_Land\#/media/File:Map_of_Franz_Josef_Land-en.svg

[2] RRHMI-WDC website (Obninsk, Russian Federation, http://www.meteo.ru)

[3] TM-1 (AARI funds, http://www.aari.ru)

[4] National Centers for Environmental Information (Asheville, USA, https://www.ncdc.noaa.gov)

[5] NOAA-CIRES-DOE $20^{\text {th }}$ Century Reanalysis V3 https://www.esrl.noaa.gov/psd/data/gridded/data.20thC_ReanV3.html 